\title{
Synthesis and Evaluation of Fenofibric Acid Ester Derivatives: Studies of Different Formulation with Their Bioavailability and Absorption Conditions
}

\author{
Zhixiang Lv, ${ }^{a}$ Zhou Wang, ${ }^{b}$ Fuyan Xiao ${ }^{c}$ and Guofan Jin ${ }^{\circledR *, c}$ \\ ${ }^{a}$ Department of Pharmacy, Danyang People's Hospital, 212300 Danyang, P. R. China \\ ${ }^{b}$ College of Vanadium and Titanium, Panzhihua University, 617000 Panzhihua, P. R. China \\ 'School of Pharmacy, Jiangsu University, 212013 Zhenjiang, P. R. China
}

\begin{abstract}
A series of fenofibric acid ester pro-drugs (JF-1-7) were synthesized. The pharmacokinetic properties of these pro-drugs were examined after oral administration to rats at a dose of $20 \mathrm{mg} \mathrm{kg}^{-1}$ to evaluate the relative bioavailability in rats. The bioavailability of the ester compounds, JF-1, $\mathbf{2}, \mathbf{3}, \mathbf{4}, \mathbf{5}, \mathbf{6}$, and $\mathbf{7}$, was significantly higher than that of fenofibrate. In particular, JF-2 proved to be most promising. The oral administration $\left(20 \mathrm{mg} \mathrm{kg}^{-1}\right)$ of JF-2 showed a relative bioavailability of approximately $272.8 \%$ compared to fenofibrate.
\end{abstract}

Keywords: pharmacokinetic properties, fenofibrate, fenofibric acid, bioavailability

\section{Introduction}

Fenofibrate (Figure 1) is a pro-drug that is pharmacologically inactive and undergoes rapid hydrolysis at the ester bond to form the active metabolite fenofibric acid. ${ }^{1}$ As a third-generation fenofibric acid derivative, fenofibrate is used mainly as a monotherapy to reduce elevated low-density lipoprotein cholesterol, total cholesterol, triglycerides, and apolipoprotein B levels; increase high-density lipoprotein cholesterol levels in patients with primary hyperlipidemia or mixed dyslipidemia; and reduce the triglyceride levels in patients with severe<smiles>CC(C)OC(=O)C(C)(C)Oc1ccc(C(=O)c2ccc(Cl)cc2)cc1</smiles>

Fenofibrate<smiles>COC(=O)C(C)(C)Oc1ccc(C(=O)c2ccc(Cl)cc2)cc1</smiles>

Glucuronide fenofibric acid hypertriglyceridemia. On the other hand, fenofibrate is a neutral, lipophilic compound that is practically insoluble in water, making it challenging to achieve consistent therapeutic levels. ${ }^{2,3}$ One of the main disadvantages of this drug is the low consistently achieved therapeutic levels, because of its special chemical characteristics, such as its high lipophilicity, and low water-solubility. ${ }^{4,5}$

This study examined the bioavailability and absorption of various fenofibrate formulations. ${ }^{6-8}$ Furthermore, a series of fenofibrates were prepared with different formulations to increase its overall solubility. Four known (JF-1 to 4) and three (JF-5 to $\mathbf{7}$ ) novel pro-drugs (Figure 2) were<smiles>CC(C)(Oc1ccc(C(=O)c2ccc(Cl)cc2)cc1)C(=O)O</smiles>

Fenofibric acid<smiles>CC(C)(Oc1ccc(C(=O)c2ccc(Cl)cc2)cc1)C(=O)O[Na]</smiles>

Choline salt fenofibric acid

Figure 1. Fenofibric acid derivatives.

\footnotetext{
*e-mail: 1000004770@ujs.edu.cn
} 
synthesized using side chain halide intermediates. The main development of these derivatives is to change fenofibric acid to a fenofibric acid prodrug ester. ${ }^{9}{ }^{10}$ A series of fenofibrate derivatives were synthesized based on the screened pharmacokinetic properties of highly water-soluble lead compounds. ${ }^{11-14}$

\section{Experimental}

\section{General}

The ${ }^{1} \mathrm{H}$ nuclear magnetic resonance (NMR) spectra were taken at JEOL ECLITSE-300 Spectrometer (Japan). The chemical shifts are reported in parts per million (ppm) downfield relative to TMS (tetramethylsilane) as the internal standard (IS). The mass spectra (MS) were recorded on a Thermo Fisher (LCQ Fleet, Japan). The matrix-assisted laser desorption/ionization-time of flight (MALDI-TOF) mass spectra were recorded on a VoyagerDE STR (Japan). Silica gel (200-230 mesh) was used for open column chromatography. Thin layer chromatography (TLC) was performed on silica gel 60 F254 (Merck<smiles>Cc1oc(=O)oc1COC(=O)C(C)(C)Oc1ccc(C(=O)c2ccc(Cl)cc2)cc1</smiles>

JF-1<smiles>CC(C)(Oc1ccc(C(=O)c2ccc(Cl)cc2)cc1)C(=O)OCCN1CCOCC1</smiles>

JF-3<smiles>CC(C)(Oc1ccc(C(=O)c2ccc(Cl)cc2)cc1)C(=O)OCCOC(=O)N1CCOCC1</smiles>

JF-5<smiles>Cc1ccc(S(=O)(=O)O)cc1CS(=O)(=O)OCCOC(=O)C(N)C(C)C</smiles>

$\mathrm{JF}-7$
DGaA, Germany). All solvents were freshly distilled from proper dehydrating agents under argon gas. All necessary chemicals were purchased from Sigma-Aldrich Corp. (USA) unless specified otherwise. JF-2, fenofibrate, and fenofibric acid were supplied by J2H Biotech (Ansan, South Korea). Sildenafil, an internal standard for highperformance liquid chromatography (HPLC) analysis, was purchased from Sigma-Aldrich Corp. (St. Louis, MO, USA). Acetonitrile and methanol were products from Burdick \& Jackson (Muskegon, MI, USA). Polyethylene glycol 400 (PEG-400) was a product from Showa Chemical Corp. (Tokyo, Japan). All other chemical were of reagent or HPLC grade.

\section{Syntheses}

Synthesis of (4-chlorophenyl)(4-hydroxyphenyl)methanone

$\mathrm{AlCl}_{3}(4.0 \mathrm{~g}, 30 \mathrm{mmol})$ was added slowly to a stirred solution of anisole $(2.16 \mathrm{~g}, 20 \mathrm{mmol})$ in dry toluene at $0{ }^{\circ} \mathrm{C}$ in an inert atmosphere. 4-Chlorobenzoyl chloride (3.5 g, $20 \mathrm{mmol}$ ) was added dropwise via a cannula. The reaction mixture was heated slowly under reflux for $1.5 \mathrm{~h}$, and the<smiles>CC(=O)OCCOC(=O)C(C)(C)Oc1ccc(C(=O)c2ccc(Cl)cc2)cc1</smiles>

JF-2<smiles>CC(C)(C)C(=O)OCOC(=O)C(C)(C)Oc1ccc(C(=O)c2ccc(Cl)cc2)cc1</smiles>

JF-4<smiles>CC(C)[C@H](N)C(=O)OCCOC(=O)C(C)(C)Oc1ccc(C(=O)c2ccc(Cl)cc2)cc1</smiles>
JF-6

Figure 2. Series of fenofibric acid derivatives JF-1-7. 
reaction was monitored by TLC. When the reaction was complete, it was cooled to room temperature, and then quenched slowly with $40 \mathrm{~mL}$ of distilled water. The crude product was washed with sufficient water and recrystallized with ethanol to give (4-chlorophenyl)(4-hydroxyphenly) methane as a white solid (3.86 g, 83\%). ${ }^{1} \mathrm{H}$ NMR $(300 \mathrm{MHz}$, $\left.\mathrm{CDCl}_{3}\right) \delta$ 7.75-6.89 (m, 8H), $5.66(\mathrm{~s}, 1 \mathrm{H})$.

\section{Synthesis of fenofibric acid}

$\mathrm{NaOH}(0.6 \mathrm{~g}, 15 \mathrm{mmol})$ was added to a stirred solution of (4-chlorophenyl) (4-hydroxyphenyl) methanone (3.49 g, $15 \mathrm{mmol})$ in dry 2-butanone $(60 \mathrm{~mL})$. The reaction mixture was heated under reflux for $1 \mathrm{~h}$ and isopropyl-(2-bromo2-methyl)-propanonate (3.76 g) in dry 2-butanone ( $15 \mathrm{~mL})$ was then added. The reaction mixture was heated under reflux for $8 \mathrm{~h}$ until the reaction was complete. Subsequently, $1 \mathrm{M} \mathrm{NaOH} 50 \mathrm{~mL}$ was added to the reaction, and the resulting mixture was heated under reflux for $4 \mathrm{~h}$. The residue was partitioned between water with brine $(20 \mathrm{~mL})$ and $\mathrm{CH}_{2} \mathrm{Cl}_{2}(80 \mathrm{~mL})$. The separated organic layer was washed with brine $(20 \mathrm{~mL})$, dried over anhydrous sodium sulfate, filtered, concentrated, and recrystallized with acetone to give fenofibric acid as a white powder $(4.3 \mathrm{~g}$, $90 \%) .{ }^{1} \mathrm{H} \mathrm{NMR}\left(300 \mathrm{MHz}, \mathrm{CDCl}_{3}\right) \delta 11.2(\mathrm{~s}, 1 \mathrm{H}), 7.75-6.93$ $(\mathrm{m}, 8 \mathrm{H}), 1.70(\mathrm{~m}, 6 \mathrm{H})$.

Synthesis of fenofibric acid derivative analogous

\section{General procedure}

A solution of 4-chloromethyl-5-1,3-dioxolen-2-one $(2.94 \mathrm{~g}, 20 \mathrm{mmol})$ was added to fenofibric acid (3.18 g, $10 \mathrm{mmol})$ and $\mathrm{K}_{2} \mathrm{CO}_{3}(2.76 \mathrm{~g}, 20 \mathrm{mmol})$ in $\mathrm{N}, \mathrm{N}$-dimethylacetamide $(64 \mathrm{~mL})$ at room temperature at such a rate that the reaction maintained an internal temperature of $60-65{ }^{\circ} \mathrm{C}$ overnight. The reaction mixture was cooled to $0{ }^{\circ} \mathrm{C}$ and water $(100 \mathrm{~mL})$ was added slowly. The resulting mixture was stirred at room temperature for $1.5 \mathrm{~h}$, extracted with ethyl acetate $(100 \mathrm{~mL})$, and washed with brine $(150 \mathrm{~mL} \times 3)$. The solvent was distilled off under reduced pressure to obtain a residue. The residue was purified further by column chromatography to give the title compounds. The following compounds were synthesized according to this procedure.

Synthesis of (5-methyl-2-oxo-1,3-dioxol-4-yl)-methyl2-(4-(4-chlorobenzoyl)phenxoy)-2-methylpropanonate (JF-1)

This was obtained $4.0 \mathrm{~g}$ as a white solid. Yield: $93 \%$; ${ }^{1} \mathrm{H}$ NMR (300 MHz, dimethyl sulfoxide (DMSO- $\left.d_{6}\right)$ ) $\delta$ 7.69-7.65 (m, 4H), 7.60-7.58 (d, 2H, J 6.3 Hz), 6.87-6.85 (d, 2H, J $6.6 \mathrm{~Hz}), 5.08$ (s, 2H), 2.11 (s, 3H), 1.61 (s, 6H);
MS (MALDI-TOF) $m / z$, calcd. for $\mathrm{C}_{22} \mathrm{H}_{19} \mathrm{ClO}_{7}[\mathrm{M}-\mathrm{H}]^{-}$: 430.1105, found: 430.1013 .

Synthesis of 2-acetoxyethyl-2-(4-(4-chlorobenzoyl) phenoxy)-2-methylpropanonate (JF-2)

This was obtained $3.4 \mathrm{~g}$ as a colorless oil liquid. Yield: $85 \%$; ${ }^{1} \mathrm{H}$ NMR (300 MHz, DMSO- $\left.d_{6}\right) \delta 7.70-7.68(\mathrm{~m}, 4 \mathrm{H})$, 7.60-7.58 (d, 2H, J 6.3 Hz), 6.90-6.88 (d, 2H, J 6.3 Hz), 4.43-4.32 (t, 2H, J 3.3 Hz), 4.18-4.15 (t, 2H, J 3.3 Hz), 1.88 (s, 3H), 1.60 (s, 6H); MS (MALDI-TOF) $\mathrm{m} / \mathrm{z}$, calcd. for $\mathrm{C}_{21} \mathrm{H}_{21} \mathrm{ClO}_{6}[\mathrm{M}-\mathrm{H}]^{-}$: 404.0942, found: 404.0921.

Synthesis of 2-morpholinoethyl-2-(4-(4-chlorobenzoyl) phenoxy)-2-methylpropanonate (JF-3)

This was obtained $3.5 \mathrm{~g}$ as a white solid. Yield: $81 \%$; ${ }^{1} \mathrm{H}$ NMR (300 MHz, DMSO-d $d_{6} \delta$ 7.69-7.67 (m, 4H), 7.60-7.58 (d, 2H, J 6.3 Hz), 6.90-6.88 (d, 2H, J 6.3 Hz), 5.80 (s, 2H), 1.59 (s, 6H), 1.07 (s, 9H); MS (MALDI-TOF) $m / z$, calcd. for $\mathrm{C}_{23} \mathrm{H}_{26} \mathrm{ClNO}_{5}[\mathrm{M}-\mathrm{H}]^{-}: 431.139$, found: 431.1136 .

Synthesis of (2-(4-(4-chlorobenzoyl)phenoxy)-2-methylpropanoyloxy)methylpivalate (JF-4)

This was obtained $4.0 \mathrm{~g}$ as a white solid. Yield: 93\%; ${ }^{1} \mathrm{H}$ NMR (300 MHz, DMSO- $\left.d_{6}\right) \delta$ 7.69-7.67 (m, 4H), 7.60-7.58 (d, 2H, J 6.3 Hz), 6.90-6.88 (d, 2H, J 6.3 Hz), 5.80 (s, 2H), 1.59 (s, 6H), 1.07 (s, 9H); MS (MALDI-TOF) $\mathrm{m} / \mathrm{z}$, calcd. for $\mathrm{C}_{23} \mathrm{H}_{25} \mathrm{ClO}_{6}[\mathrm{M}-\mathrm{H}]^{-}$: 432.0911, found: 432.0845 .

Synthesis of (2-(4-(4-chlorobenzoyl)phenoxy)-2-methylpropanoyloxy)ethylmorpholine-4-carboxylate (JF-5)

This was obtained $4.1 \mathrm{~g}$ as a white solid. Yield: $86 \%$; ${ }^{1} \mathrm{H}$ NMR (300 MHz, DMSO- $\left.d_{6}\right) \delta$ 7.70-7.67 (m, 4H), $7.60-7.58$ (d, J 6.3 Hz, 2H), 6.90-6.88 (d, 2H, J 6.6 Hz), 4.35-4.33 (t, 3H, J 3.3 Hz), 4.18-4.16 (t, 3H, J $3.3 \mathrm{~Hz})$, 3.43 (br, 4H), 3.18 (br, 4H), $1.60(\mathrm{~s}, 6 \mathrm{H}) ;{ }^{13} \mathrm{C} \mathrm{NMR}$ $\left(75 \mathrm{MHz}, \mathrm{DMSO}-d_{6}\right) \delta 206.1,184.5,183.6,131.4,131.2$, $130.8,130.7,130.4,128.5,126.8,123.0,85.5,85.0,30.4$, 29.9, 23.1, 22.0, 21.5; MS (MALDI-TOF) $\mathrm{m} / \mathrm{z}$, calcd. for $\mathrm{C}_{24} \mathrm{H}_{26} \mathrm{ClNO}_{7}[\mathrm{M}-\mathrm{H}]^{-}:$475.1279, found: 475.1283 .

Synthesis of (2-(4-(4-chlorobenzoyl)phenoxy)-2-methylpropanoyloxy)ethyl-2-amino-3-methylbutanonate monobenzenesulfonate (JF-6)

This was obtained $5.1 \mathrm{~g}$ as a white solid. Yield: $82 \%$; ${ }^{1} \mathrm{H}$ NMR (300 MHz, DMSO- $\left.d_{6}\right) \delta 8.27$ (s, 2H), 7.71-7.57 (m, 6H), 7.31-7.27 (m, 3H), 6.91-6.89 (d, 2H, J 6.3 Hz), 4.44-4.34 (m, 4H), 3.88-3.87 (d, 1H, J 3.0 Hz), 2.11 (m, $1 \mathrm{H}), 1.60(\mathrm{~s}, 6 \mathrm{H}), 0.91-0.86(\mathrm{~m}, 6 \mathrm{H}) ;{ }^{13} \mathrm{C} \mathrm{NMR}(75 \mathrm{MHz}$, DMSO- $\left.d_{6}\right) \delta 206.9,184.5,163.3,147.1,138.8,130.7$, 130.6, 130.3, 129.7, 128.7, 128.6, 124.1, 123.8, 85.8, 28.6, 
23.0, 21.8, 21.7, 16.4, 16.2; MS (MALDI-TOF) $\mathrm{m} / z$, calcd. for $\mathrm{C}_{30} \mathrm{H}_{34} \mathrm{ClNO}_{9} \mathrm{~S}[\mathrm{M}-\mathrm{H}]^{-}:$619.2147, found: 619.2136.

Synthesis of (2-(4-(4-chlorobenzoyl)phenoxy)-2-methylpropanoyloxy)ethyl-2-amino-3-methylbutanonate monotosylate (JF-7)

This was obtained $4.9 \mathrm{~g}$ as a white solid. Yield: $77 \%$; ${ }^{1} \mathrm{H}$ NMR $\left(300 \mathrm{MHz}\right.$, DMSO- $\left.d_{6}\right) \delta 8.26$ (s, 2H), 7.71-7.61 $(\mathrm{m}, 4 \mathrm{H}), 7.60-7.59(\mathrm{~d}, 2 \mathrm{H}, J 6.3 \mathrm{~Hz}), 7.47-7.45(\mathrm{~d}, 2 \mathrm{H}$, $J$ 6.3 Hz), 7.10-7.08 (d, 2H, J 5.7 Hz), 6.91-6.89 (d, 2H, $J 6.3 \mathrm{~Hz}), 4.44-4.30$ (m, 4H), 3.87-3.86 (d, 1H, J $3.3 \mathrm{~Hz})$, $2.26(\mathrm{~s}, 3 \mathrm{H}), 2.11(\mathrm{~m}, 1 \mathrm{H}), 1.60(\mathrm{~s}, 6 \mathrm{H}), 0.91-0.86(\mathrm{~m}$, $6 \mathrm{H}) ;{ }^{13} \mathrm{C}$ NMR $\left(75 \mathrm{MHz}, \mathrm{DMSO}-d_{6}\right) \delta 206.5,184.2$, 165.7, 145.3, 138.4, 138.3, 132.6, 130.5, 130.3, 130.1, $129.9,128.4,124.9,123.3,122.2,100.3,87.5,85.7$, 30.6, 23.1, 22.0, 21.4; MS (MALDI-TOF) $\mathrm{m} / z$, calcd. for $\mathrm{C}_{31} \mathrm{H}_{36} \mathrm{ClNO}_{9} \mathrm{~S}[\mathrm{M}-\mathrm{H}]^{-}:$633.1581, found: 633.1572.

\section{Biology}

Preparation of the calibration standards and quality control samples

A stock solution of fenofibric acid $\left(1 \mathrm{mg} \mathrm{mL}^{-1}\right)$ was prepared in methanol. The appropriate dilutions of the stock solution of fenofibric acid were then prepared with methanol $(0.003,0.005,0.01,0.02,0.05,0.1,0.2,0.5$, or $\left.1 \mathrm{mg} \mathrm{mL}^{-1}\right)$. Standard solutions of fenofibric acid in rat plasma were prepared by spiking with the appropriate volume (10 $\mathrm{mg} \mathrm{mL}^{-1}$ of plasma) of the diluted stock solutions, giving final concentrations of $0.03,0.05,0.1$, $0.2,0.5,1,2,5$, or $10 \mathrm{mg} \mathrm{mL}^{-1}$ for plasma. The IS working solution was prepared by dissolving sildenafil in acetonitrile to give a final concentration of $10 \mathrm{mg} \mathrm{mL}^{-1}$.

\section{Preparation of plasma samples}

A $50 \mu \mathrm{L}$ aliquot of the sample was deproteinized with $75 \mu \mathrm{L}$ of acetonitrile containing $1 \mu \mathrm{g} \mathrm{mL}^{-1}$ sildenafil (an
IS). After vortex-mixing and centrifugation at $3000 \mathrm{rpm}$ for $10 \mathrm{~min}$, the supernatant was transferred to a vial and a $20 \mu \mathrm{L}$ aliquot was injected directly into the HPLC column. ${ }^{15-25}$

\section{HPLC analysis}

The HPLC system consisted of a Gilson-234 auto sampler (Gilson, Middleton, WI, USA), a Gilson 307 pump (Gilson), a capcell PACK (C18) column $(250 \times 4.6 \mathrm{~mm}$, i.d.: particle size, $5 \mathrm{~mm}$, Shiseido, Tokyo, Japan), a model UV-118 UV/VIS detector (Gilson), and a model Gilson unipoint system software (Gilson). The mobile phase, $0.02 \mathrm{M}$ ammonium acetate buffer:acetonitrile (35:36, v/v), was run at a flow rate of $1.0 \mathrm{~mL} \mathrm{~min}^{-1}$, and the column eluent was monitored using an ultraviolet detector at $280 \mathrm{~nm}$ at room temperature. The retention times of sildenafil (an internal standard) and fenofibric acid were approximately 5.9 and $7.7 \mathrm{~min}$, respectively (Figure 3)..$^{26-32}$

\section{Analytical method validation}

The analytical method was validated with regard to its specificity, linearity, intra- and interday precision and accuracy, matrix effect, and stability according to the US Food and Drug Administration. ${ }^{33}$

\section{Pharmacokinetic and statistical analyses}

The total area under the plasma concentration-time curve to the last time (AUClast), maximum plasma concentration $\left(\mathrm{C}_{\max }\right)$, time to reach $\mathrm{C}_{\max }\left(\mathrm{T}_{\max }\right)$, and half-life $\left(\mathrm{T}_{1 / 2}\right)$ were estimated using noncompartmental calculations carried out with WinNonlinTM 5.2. ${ }^{34}$ All data are expressed as the mean \pm standard deviation (SD). The statistical significance of the differences between the 2 groups was analyzed using a Student's $t$-test carried out with SPSS..$^{35}$ A $p$-value $<0.05$ was considered significant. ${ }^{36-42}$

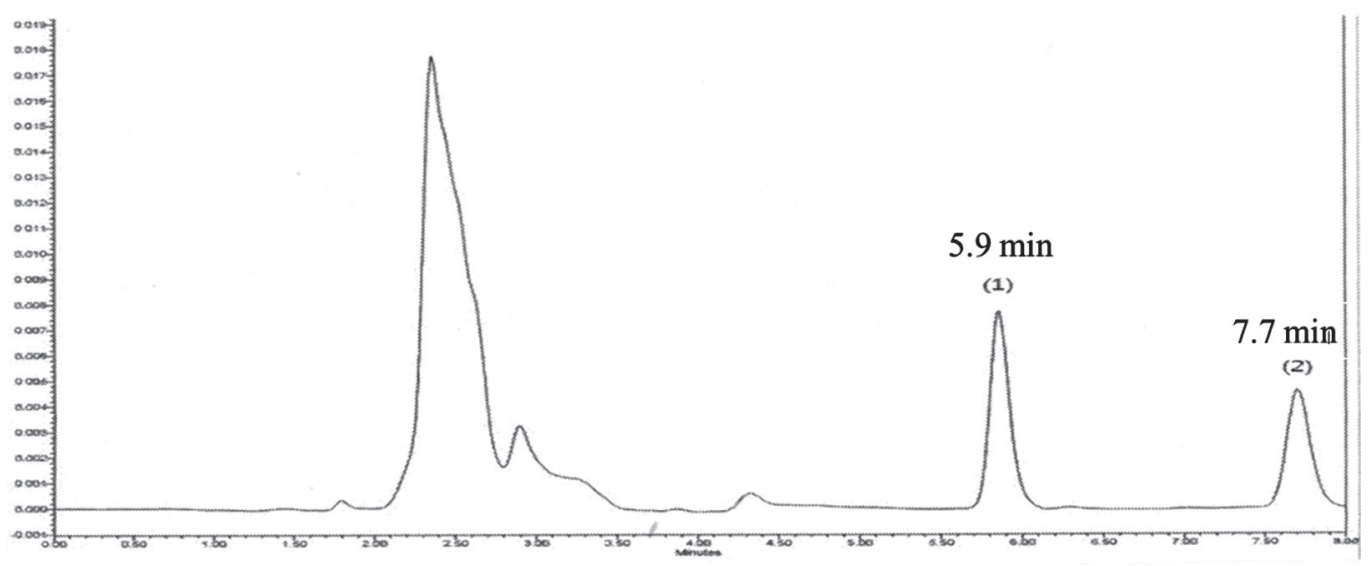

Figure 3. Representative HPLC chromatograms after deproteinization of drug-free rat plasma peaks: fenofibric acid (1) (5.9 min) and (2) (7.7 min). 


\section{Animal experiments}

The care and the use of experimental animals is in accordance to the Laboratory Animal Ethics Committee Sam Yang Company, South Korea (KR20170325142674).

Male Sprague-Daley rats, 6-8 week old and weighing 220-300 g, were purchased from Bio-Korea (Osan, South Korea). The rats were maintained in a clean room at between $23 \pm 2{ }^{\circ} \mathrm{C}$ with $12 \mathrm{~h}$ light (7:00 am-7:00 pm) and dark (7:00 pm-7:00 am) cycles, and a relative humidity of $55 \pm 5 \%$. The rats were housed in metabolic cages (Tecniplast, Varese, Italy) under filtered pathogen-free air and with food (Sam Yang Company, PyeongTaek, South Korea) and water supplied ad libitum. The rats were fasted overnight before drug administration and for $4 \mathrm{~h}$ after dosing. JF-2 was dissolved in PEG-400:distilled water $1: 1(\mathrm{v} / \mathrm{v})$ to make a concentration of $5 \mathrm{mg} \mathrm{mL}^{-1}$. The rats were placed in a restrainer and administered a dose of $20 \mathrm{mg} \mathrm{kg}^{-1}$ orally. Blood was collected in a heparinized tube at the pre-dose stage, and at $0.25,0.5,1,2,4,6,8,10$, and $12 \mathrm{~h}$ after p.o. administration. Plasma was harvested after centrifugation at $3000 \mathrm{rpm}$ and $4{ }^{\circ} \mathrm{C}$ for $10 \mathrm{~min}$ and stored frozen at $-70{ }^{\circ} \mathrm{C}$ until it was analyzed. ${ }^{43-49}$

\section{Results and Discussion}

\section{Chemistry}

A general procedure for the preparation of the fenofibric acid pro-drug began from a serial reaction, such as Friedel-crafts arylation, demethylation, deprotection, esterhydrolysis under basic conditions.

A series of fenofibric acid esters, JF-1-7, were prepared using the optimized procedure from the starting material, 4-chlorobenzoylchloride and anisole, dissolved in dry dichloromethane using aluminum chloride as the Friedel-craft reagent to afford (4-chlorophenyl) (4-hydroxyphenyl)methanone. The addition of isopropyl2-bromo-2-methylpropanoate gave the fenofibrate, which was then treated with a $1 \mathrm{M} \mathrm{NaOH}$ solution to hydrolyze the ester to the acid form in the presence of the desired fenofibric acid compound (Scheme 1). Finally, fenofibric acid ester compounds were generated from fenofibric acid and side alkyl halide chain reagents was treated with potassium carbonate to produce the target compounds JF-1-7 (Scheme 2).

Plasma samples were collected after the oral administration of JF-2 and fenofibrate and the concentrations of fenofibric acid were determined using a validated HPLC method (Figure 4). The mean plasma concentrationtime curves for fenofibric acid were measured after the oral administration of JF-2 and fenofibrate to rats; the pharmacokinetic parameters are presented. After the oral administration of JF-2, the absorption of fenofibric acid from the rat portal vein was slow and the plasma concentrations of fenofibric acid decreased in a delayreleased manners with a $\mathrm{T}_{\max }$ and half-life of 6.0 and $7.9 \mathrm{~h}$, respectively. The estimated total body clearance was $33.0 \mathrm{~mL} \mathrm{~min}^{-1} \mathrm{~kg}^{-1}$, which was considerably smaller than the reported cardiac output of $295 \mathrm{~mL} \mathrm{~min}^{-1} \mathrm{~kg}^{-1}$ based on the blood data in rats. ${ }^{50}$ This suggests that the first-pass effect of JF-2 in the lung and heart could be almost negligible in rats.

The maximum plasma concentrations of fenofibric acid were achieved 6.0 and $4.0 \mathrm{~h}$ after the oral administration of JF-1-7 and fenofibrate, respectively (Table 1). The $\mathrm{C}_{\max }$ values of JF-2 and fenofibrate were $39.19 \pm 6.65$ and $22.78 \pm 3.68 \mathrm{mg} \mathrm{mL}^{-1}$, and the AUClast values were $343.13 \pm 61.79$ and $125.80 \pm 22.42 \mathrm{mg} \mathrm{mL}^{-1}$ for JF-2 and fenofibrate, respectively (Table 2). The $\mathrm{C}_{\max }$ value of JF-2 was 1.7 times higher than that of fenofibrate and the AUClast value of JF-2 was 2.7 times higher than that of fenofibrate. JF-2 appeared to have been well absorbed

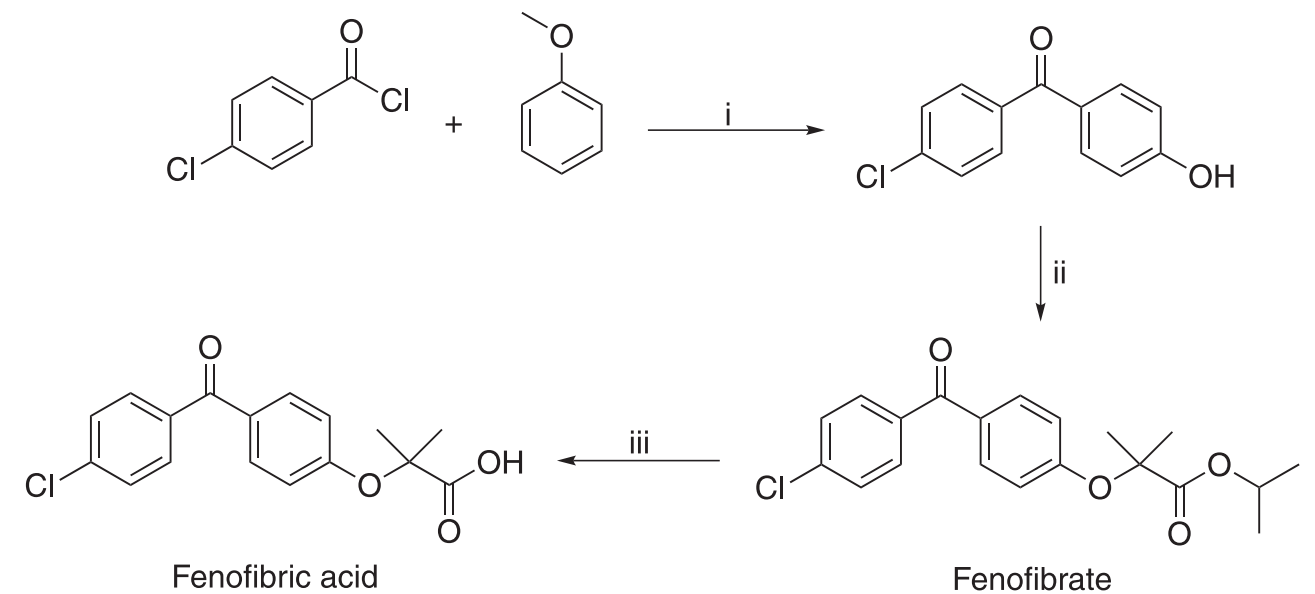

Scheme 1. Reagents and conditions: (i) $\mathrm{AlCl}_{3}$, toluene, $0^{\circ} \mathrm{C}$; (ii) isopropyl 2-bromo-2-methylpropanotate, $\mathrm{K}_{2} \mathrm{CO}_{3}$, DMA; (iii) $1 \mathrm{M} \mathrm{NaOH}$, 2-butaonone, reflux. 


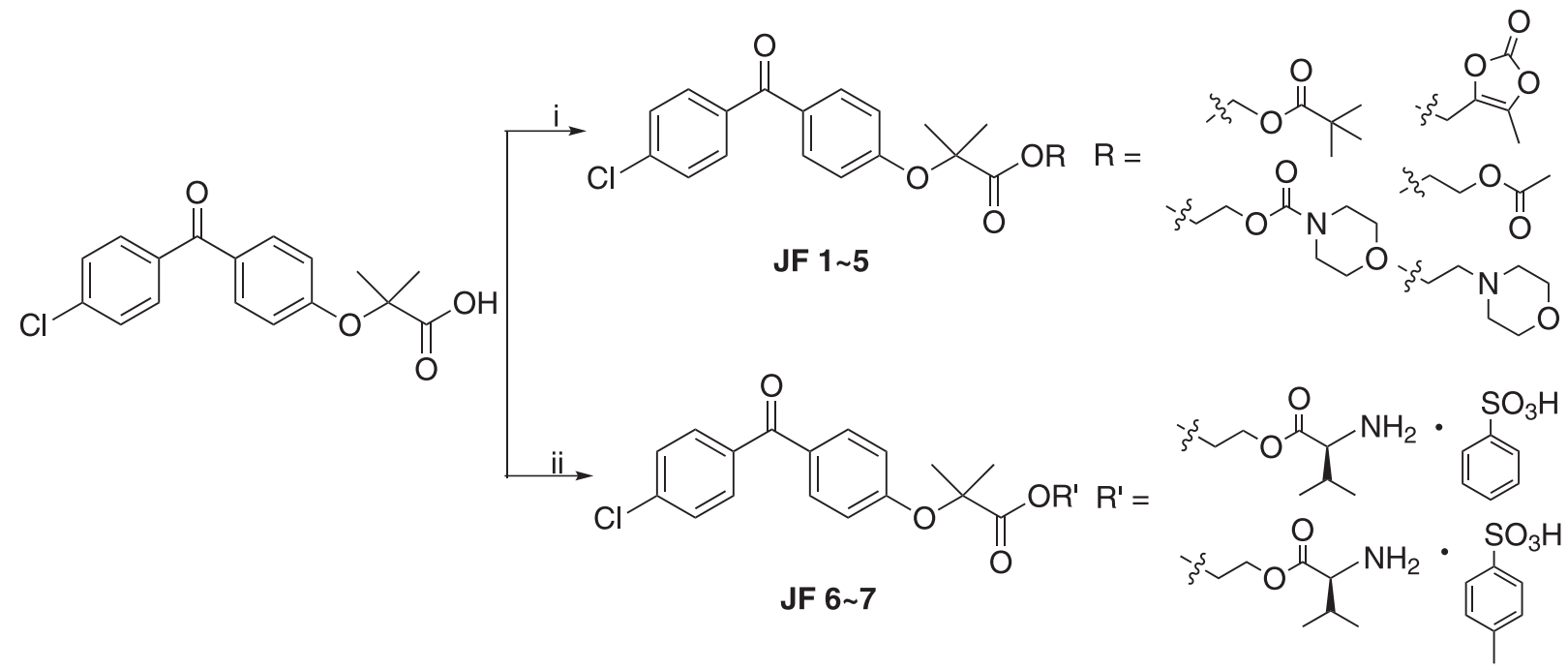

Scheme 2. Reagents and conditions: (i) $\mathrm{K}_{2} \mathrm{CO}_{3}$, DMF, $65^{\circ} \mathrm{C}$; (ii) ethyl L-valinate, aryl sulfonic acid, THF.

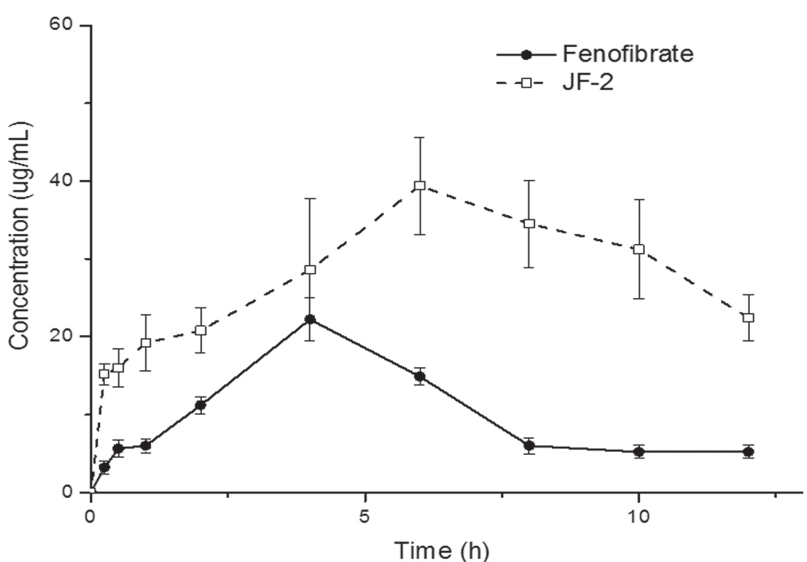

Figure 4. Comparative pharmacokinetics of JF-2 and fenofibrate after oral administration to rats.

Table 1. Comparison of JF series compounds and fenofibrate values

\begin{tabular}{lccc}
\hline Compound & $\begin{array}{c}\mathrm{AUC}_{0-12} / \\
\left(\mu \mathrm{g} \mathrm{h} \mathrm{mL}^{-1}\right)\end{array}$ & $\begin{array}{c}\mathrm{C}_{\max } / \\
\left(\mu \mathrm{gL}^{-1}\right)\end{array}$ & $\mathrm{BA} / \%$ \\
\hline JF-1 & $61.28 \pm 21.64$ & $8.65 \pm 3.24$ & 48.7 \\
JF-2 & $343.13 \pm 61.79$ & $39.19 \pm 6.65$ & 272.8 \\
JF-3 & $157.03 \pm 31.33$ & $29.61 \pm 5.78$ & 124.8 \\
JF-4 & $167.14 \pm 28.39$ & $19.05 \pm 3.23$ & 132.9 \\
JF-5 & $157.58 \pm 26.83$ & $22.41 \pm 4.44$ & 125.3 \\
JF-6 & $112.20 \pm 21.13$ & $15.57 \pm 2.54$ & 89.2 \\
JF-7 & $156.09 \pm 11.77$ & $25.50 \pm 1.80$ & 124.1 \\
Fenofibrate & $125.80 \pm 22.42$ & $22.78 \pm 3.68$ & -
\end{tabular}

AUC: area under the curve to the collected time point; $\mathrm{C}_{\max }$ : peak plasma concentration; BA: bioaggregate.

from the gastrointestinal tract compared to fenofibrate. The $p$-value of $\mathrm{C}_{\max }$ and AUClast between the 2 groups were 0.020 and 0.005 , respectively. This suggests that JF-2 was well absorbed from the gastrointestinal tract
Table 2. Pharmacokinetic parameters of fenofibric acid after a single oral administration of JF-2 and fenofibrate at dose of $20 \mathrm{mg} \mathrm{kg}^{-1}$ to male rats

\begin{tabular}{lcc}
\hline Parameter & JF-2 $(\mathrm{n}=5)$ & Fenofibrate $(\mathrm{n}=5)$ \\
\hline $\mathrm{AUC}_{0-12} /\left(\mathrm{g} \mathrm{h} \mathrm{mL}^{-1}\right)$ & $343.13 \pm 61.79$ & $125.80 \pm 22.42$ \\
$\mathrm{C}_{\max } /\left(\mathrm{g} \mathrm{mL}^{-1}\right)$ & $39.19 \pm 6.65$ & $22.78 \pm 3.68$ \\
$\mathrm{~T}_{\max } / \mathrm{h}$ & $6.00 \pm 0.00$ & $4.00 \pm 0.00$ \\
$\mathrm{~T}_{1 / 2} / \mathrm{h}$ & $7.89 \pm 1.49$ & $3.46 \pm 0.78$ \\
\hline
\end{tabular}

Data represent mean \pm standard deviation $(\mathrm{SD} ; \mathrm{n}=5)$. AUC: area under the curve to the collected time point; $\mathrm{C}_{\max }$ : peak plasma concentration; $\mathrm{T}_{\max }$ : time to reach the peak plasma concentration; $\mathrm{T}_{1 / 2}$ : elimination half-life.

via peptide transporter 1 . The considerable effect of JF-2 on peptide transporter 1 is being tested based on homogenate studies.

\section{Conclusions}

A series of fenofibric acid-substituted polar-function derivatives, such as dioxolone, alkyl acetate, alkyl none, morpholinyl carboxylate, ethyl L-valinate, and sulfonic acid salt, were synthesized. The coupling of the fenofebric acid with chain functional groups to produce the target compounds proceeded successfully, which can be further one-top substituted to produce the final compound in moderate yield. The effects of synthesized compounds on the biology assay in pharmacokinetics showed outstanding bioavailability. In particular, fenofebric acid and acetatecontaining compound code JF-2, showed strong absorption and a high concentration. Overall, JF-2 is a type of prodrug with potential activity. JF-2 is a special product that is closely related to human health. Further studies to find the optimal conditions for fenofibric acid are currently underway. 


\section{Supplementary Information}

Supplementary information (NMR spectrum) is available free of charge at http://jbcs.sbq.org.br as PDF file.

\section{Acknowledgments}

This study was supported financially by the talent introduction of scientific research foundation of Jiangsu University (grant No. 5501290005). All biological experiment supported by Bio-Korea Research and Sam Yang Company, Republic of Korea.

\section{References}

1. Arunachalam, S.; Vaibhav, P. C.; Ragupathi, A.; Hwang, K. C.; J. Am. Chem. Soc. 2017, 139, 2896.

2. Bandgar, B. P.; Saranghar, R. J.; Khan, F.; Mookkan, J.; Shetty, P.; Sing, H. G.; J. Med. Chem. 2011, 54, 5915.

3. Builders, P. F.; Lbekwe, N.; Okpako, L. C.; Attama, A. A.; Kunle, O. O.; Eur. J. Pharm. Biopharm. 2009, 72, 34.

4. Bukara, K.; Schueller, L.; Rosier, J.; Martens, M. A.; Daems, T.; Verheyden, L.; Eelen, S.; Speybroeck, M. V.; Libanati, C.; Martens, J. A.; Mooter, G. V. D.; Frérart, F.; Jolling, K.; Gieter, M. D.; Bugarski, B.; Kiekens, F.; Eur. J. Pharm. Biopharm. 2016, 108, 220.

5. Chen, Y.; Yuan, L.; Zhou, L.; Zhang, Z. H.; Cao, W.; Wu, Q. Q.; Int. J. Nanomed. 2012, 7, 458.

6. Chu, C.; Tong, S. S.; Xu, Y.; Wang, L.; Fu, M.; Ge, Y. R.; Yu, J. N.; Xu, X. M.; Acta Pharmacol. Sin. 2011, 32, 973.

7. Faouzi, G.; Hocine, A.; Didier, M. L.; Christopher, R. M.; Jacques, H. P.; Lett. Org. Chem. 2008, 5, 665.

8. Islam, Md N.; Choi, R. J.; Jung, H. A.; Oh, S. H.; Choi, J. S.; Arch. Pharmacal Res. 2016, 39, 340.

9. Guivarch, P. H.; Vachon, M.; Fordyce, G.; Clin. Ther. 2004, 26 , 1456.

10. Keating, G.; Ormrod, D.; Drugs 2002, 62, 1909.

11. Kei, A.; Liberopoulos, E. N.; Mikhailidis, D. P.; Elisaf, M.; Int. J. Clin. Pract. 2013, 67, 412

12. Kim, C. H.; Ramu, R.; Jin, H. A.; Bae, M. A.; Cho, Y. S.; Mol. Cell. Biochem. 2019, 344, 91.

13. Kim, J. N.; Chin, J. W.; Im, C. Y.; Yoo, E. K.; Woo, S. Y.; Hwang, H. J.; Cho, J. H.; Seo, K. A.; Song, J. Y.; Hwang, H. Y.; Kim, K. H.; Kim, N. D.; Yoon, S. K.; Jeon, J. H.; Yoon, S. Y.; Jeon, Y. H.; Choi, H. S.; Lee, I. K.; Cho, S. J.; Eur. J. Med. Chem. 2016, 120, 338.

14. Kim, K. S.; Kim, J. H.; Jin, S. G.; Kim, D. W.; Kim, D. S.; Kim, J. O.; Yong, C. S.; Cho, K. H.; Li, D. X.; Woo, J. S.; Choi, H. G.; Arch. Pharmacal Res. 2016, 39, 531.

15. Schreiber, R.; Guendel, U.; Franz, S.; Kuester, A.; Rechenberg, B.; Altenburger, R.; Regul. Toxicol. Pharmacol. 2011, 61, 261.
16. Li, F.; Wu, X. Y.; Zou, Y. M.; Zhao, T.; Zhang, M.; Feng, W. W.; Yang, L. Q.; Food Chem. Toxicol. 2012, 50, 1623.

17. Ling, A.; Luoma, J. T.; Hilleman, D.; Cardiol. Res. 2013, $4,47$.

18. Li, Q. Q.; Sun, S. L.; Zhang, E.; Tan, K. R.; Wei, X. B.; Fan, H. W.; Li, Y. J.; Jia, X. B.; J. Pharm. Biomed. Anal. 2012, 66, 392.

19. Liu, S.; Jiang, P.; Song, G. L.; Liu, R.; Zhu, H. J.; Dyes Pigm. 2009, 81, 218 .

20. Michio, K.; Prabagaran, N.; Kallolmay, B.; Rakesh, D.; Dean, C. C.; J. Med. Chem. 2007, 50, 3973.

21. Ou-yang, Z.; Cao, X.; Wei, Y.; Zhang, W. W. Q.; Zhao, M.; Duan, J. A.; Rev. Bras. Farmacogn. 2013, 23, 776.

22. Liu, P.; Yan, J.; Gong, J.; Wang, C.; Chen, G.; Biomed. Pharmacother. 2011, 65, 193.

23. Chen, S. X.; Wu, L.; Jiang, X. G.; Feng, Y. Y.; Cao, J. P.; J. Ethnopharmacol. 2008, 118, 503.

24. Guo, D. X.; Shen, C.; Chen, Y. C.; Yang, S.; Wang, L. H.; Jin, Y.; He, L.; Chen, J.; Zhao, X.; Zhou, W.; Zhao, H.; Yao, Y.; Clin. Exp. Hypertens. 2015, 37, 420.

25. Wang, G.; Wang, J. J.; Chen, X. L.; Du, L.; Li, F.; J. Controlled Release 2016, 235, 276

26. Raza-Iqbal, S.; Tanaka, T.; Anai, M.; Inagaki, T.; Matsumura, Y.; Ikeda, K.; Taguchi, A.; Gonzalez, F. J.; Sakai, J.; Kodama, T.; J. Atheroscler. Thromb. 2015, 22, 754.

27. Škoch, K.; Císařová, I.; Štěpnička, P.; Organometallics 2016 , 35,3378 .

28. Su, S. L.; Cui, W. X.; Zhou, W.; Duan, J. A.; Shang, E.; Tang, Y. P.; Chin. Med. 2013, 8, 5.

29. Yang, H.; Chen, B.; Wang, X. B.; Chue, P.; Shen, Y. P.; Xia, G. H.; Jia, X. B.; Nat. Prod. Res. 2013, 27, 1933.

30. Feng, X.; Kong, W.; Wei, J.; Ou-Yang, Z.; Yang, M.; Pharm. Biol. 2014, 52, 362.

31. Lu, Y.; Chen, B.; Yu, M.; Han, J.; Wang, Y.; Tan, Z. J.; Yan, Y. S.; Food Chem. 2016, 210, 1.

32. Liu, J. D.; Chen, N.; Yang, J.; Yang, B.; Ouyang, Z.; Wu, C. X.; Yuan, Y.; Wang, W. H.; Chen, M.; Food Chem. 2018, 253, 284.

33. U.S. Food and Drug Administration (US FDA); Guidance for Industry, Bio-Analytical Method Validation; US FDA: Rockville, USA, 2001.

34. WinNonlinTM 5.2; Pharsight, Sunnyvale, XA, USA, 2003.

35. SPSS; IBM, Yorktown Heights, NY, USA, 2003.

36. Sun, C. Y.; Yuan, Y. Y.; Omari-Siaw, E.; Tong, S. S.; Zhu, Y.; Wang, Q. L.; Wang, Y. W.; Wei, Q. Y.; Yu, J. N.; Xu, X. M.; Curr. Pharm. Anal. 2018, 14, 41.

37. O'Shea, J. P.; Faisal, W.; Ruane-O'Hora, T.; Devine, K. J.; Kostewicz, E. S.; O’Driscoll, C. M.; Griffin, B. T.; Eur. J. Pharm. Biopharm. 2015, 96, 207.

38. Vogt, M.; Kunath, K.; Dressman, J. B.; Eur. J. Pharm. Biopharm. 2008, 68, 283.

39. Yang, L. H.; Keating, G.; Am. J. Cardiovasc. Drugs 2009, 9 , 401. 
40. Gu, Z.; Shi, X.; Omari-Siaw, E.; Yuan, Z.; Li, H.; Min, G.; Xia, Y.; Yu, J.; Xu, X.; J. Drug Delivery Sci. Technol. 2017, 37, 184.

41. Jiang, D.; Zeng, J.; Zhu, Y.; Zhou, G.; Deng, W.; Xu, X.; Yu, J.; Drug Dev. Ind. Pharm. 2016, 42, 1174.

42. Shi, F.; Zhao, Y.; Firempong, C. K.; Xu, X.; Pharm. Biol. 2016, 54, 2320.

43. Yi, C. X.; Fu, M.; Xia, C.; Tong, S. S.; Zheng, Q. F.; Firempong, C. K.; Jiang, X. Y.; Xu, X. M.; Yu, J. N.; J. Agric. Food Chem. 2013, 61, 5961.

44. Zhang, Q.; Jiang, P.; Wang, K.; Song, G. L.; Zhu, H. J.; Dyes Pigm. 2011, 91, 89.

45. Zhao, Y. Y.; Sun, C. N.; Shi, F.; Firempong, C. K.; Yu, J. N.; Xu, X. M.; Zhang, W. M.; Pharm. Biol. (Abingdon, U. K.) 2016, 54, 130.
46. Bai, J.; Zhu, Y.; Dong, Y.; J. Funct. Foods 2018, 41, 127.

47. He, W.-S.; Pan, R.-R.; Li, L.-L.; Cui, D.-D.; Wang, H.-H.; Mao, G.-H.; Chen, X.-Q.; Food Sci. Technol. Res. 2018, 24, 875.

48. Zhang, J.; Xiao, X.; Dong, Y.; Shi, L.; Xu, T.; Wu, F.; Food Funct. 2017, 8, 1132.

49. Zhu, Y.; Bai, J.; Zhang, Y.; Xiao, X.; Dong, Y.; Int. J. Food Sci. Nutr. 2016, 67, 686.

50. Zeng, C.; Jiang, W.; Tan, M.; Xing, J. G.; He, C. H.; Pharmacogn. Mag. 2016, 12, 313.

Submitted: May 8, 2019

Published online: July 23, 2019 